\title{
From Solitude to Freedom: Human Person and the Universe in Russian Religious Philosophy
}

\author{
Alexei V. Nesteruk* \\ University of Portsmouth \\ Lion Gate Building, PORTSMOUTH, PO1 3HF, UK
}

Received 13.03.2015, received in revised form 24.03.2015, accepted 19.06.2015

The paper deals with the issues of anxiety, solitude, homelessness and non-sense of human existence in the universe as they were posed and addressed in the Russian religious philosophy of the $20^{\text {th }}$ century. Russian philosophers were seeking for overcoming of the present condition of humanity through the restoration of the lost Divine image, encapsulated in the notion of personhood. The difficulty of defining personhood proceeds from the paradoxical condition of humanity in the world reflected in perennial philosophy, as well as from a fundamental unknowability of man by himself so clearly articulated by Patristic writers. The fulfillment of personhood implies the overcoming of the constraints and slavery to the rubrics of the incarnate existence in this physical world. It is in this movement that the sense of solitude and despair disappears because the whole of the human history, as well as the whole universe, are brought inside the infinite and incomprehensible subjectivity of man in the image of the Divine. Russian philosophers expressed a deep concern and care for man, the world and God through looking for the consolation of the soul of all humanity from within a limited historical period in the $20^{\text {th }}$ century's history full of apostasy and demonic inhumanity. Their hymnology to man is the perennial attempt to affirm this world as still imbued with faith, hope and love.

Keywords: freedom, man, objectification, personhood, Russian philosophy, solitude, unconditional being, universe.

DOI: $10.17516 / 1997-1370-2015-8-8-1683-1709$.

Research area: philosophy.

"The eternal silence of the infinite spaces terrifies me. Console yourself: it is not from yourself that you must expect anything: on the contrary, your expectation must lie in expecting nothing from yourself" (B. Pascal, Pensées, p. 110).

Introduction: solitude on the crossroads of anthropology and cosmology $\mathbf{y}^{1}$

The first half of the $20^{\text {th }}$ century, with its wars and revolutions initiated a philosophical response in the academia and intelligencia, asserting the tragic and ever escaping sense of the human existence, diminution of the value of human life and its "low cost" as paid by the societies and politically struggling powers

(C) Siberian Federal University. All rights reserved

* Corresponding author E-mail address: alexei.nesteruk@port.ac.uk 
attempting to impose their utopias of a universal world-order. Russian philosophers, who experienced deeper than others the turmoil and uncertainty of the surrounding world, as well as the loss of hope for humanity's reconciliation in its progression towards the eternal good, expressed the sense of this loss through a characteristic invocation of the old philosophical motives which intellectually tortured their predecessors. Their dissatisfaction and the vision of the vanity of the human attempt to find the ground for the sense of existence in this world gave rise to a cosmological anxiety leading to a question of the possibility of liberation from all chains to this world and to the search for the source of existence in the transcendent Divine. Evgenii Trubetskoi started his book "The Sense of Life", written in 1918, with the tackling of that which seemed to be inevitable in the human condition, namely the "non-sense of existence" («бессмыслица существования») indicated by him as an eternal repetition in the circle of birth and death, when "every life attempts to rise above the earth but falls anew back onto it without any hope of succeeding, mingling with the dust of the earth; and the wings by which it takes off turn out to be no more than an illusory and disappearing poetical embellishment" (Trubetskoi 1922, p. 34). ${ }^{2}$

In 1939, Nikolai Berdyaev wrote emphatically in his book on the slavery and freedom of humanity that "a condition of anguish and distress is deeply inherent in personality as such. Man feels himself to be a creature which is suspended over an abyss. And it is just in man as person, breaking away from the primitive trend to collective existence, that this feeling reaches a special degree of acuteness" (Berdyaev 1943, p. 52). ${ }^{3}$ Berdyaev accentuates the fact that in order to have an ability of being aware of the non-sense of existence and to be able to be in a state of distress one must transcend the natural level of existence to the state of "personhood". The "abyss" over which a human creature realizes its material insignificance has, according to Berdyaev, not only natural, but also social dimensions. The "abyss" is everything which symbolizes the suspension of human freedom, uniqueness and its sense of centrality in the universe, that is man as a special creature.

In a similar vein Semion Frank expressed in 1956 the human anxiety of existence without foundation: "Our self or 'soul' is conscious...of its poverty and insufficiency, of the inherent tragedy of its existence.... In so far as it attains true selfconsciousness, it is inevitably aware of its solitude and homelessness in the world of fact in which it is bound to participate and to which it is largely subordinated" (Frank 1965, p. 97). ${ }^{4} \mathrm{He}$ uses words similar to Berdyaev by asserting that it is through self-consciousness of its own internal reality that man is also conscious of its inherent instability, that it is hanging over the abyss and looses the sense of life so that all this brings it to the search of support beyond itself (Frank 1965, p. 102). In what concerns the uncertainty of a cosmic ground in human existence, which was articulated by the sciences of the first half of the $20^{\text {th }}$ century, both Berdyaev and Frank reproduce a cosmological sentiment which is famously attributed to Pascal in respect to his saying that "the eternal silence of the infinite spaces terrifies me"s. In fact, that which Berdyaev and Frank rearticulated in the $20^{\text {th }}$ century was also articulated by existential philosophers before them. It is enough to recall Kierkegaard who expressed in a dramatic form his anxiety about the impossibility to describe one's position in being: "One sticks his finger in the ground in order to judge where one is. I stick my finger in existence - it feels like nothing. Where am I? What is the 'world'? What does this word mean? Who has duped me into the whole thing, and now leaves me standing there? Who am I? How did I come into the world; why 
was I not asked, why was I not informed of the rules and regulations... How did I come to be involved in this great enterprise called actuality? Why should I be involved in it? Am I not free to decide? Am I to be forced to be part of it? Where is the manager, I would like to make a complaint!" (Kierkegaard 2009, p. 60). What is encapsulated in these questions of Kierkegaard is the longing for answering questions about the central characteristics of human existence, that is the demand for constructing an anthropology released from cosmological conditions. The lack of understanding of the foundations of the human existence naturally leads to anxiety and an acute sense of solitude in the world. As Berdyaev continues, "yearning is directed upwards and is a mark of man's higher nature" (Berdyaev 1943, pp. 52-53). ${ }^{6}$ The height of human nature is manifested exactly in its ability to perceive its own homelessness and solitude in the world. The sense of solitude and search for its ultimate ground in the world do not diminish the place of man in nature in spite of its inability to assimilate to nature. On the contrary, it is this search and anxiety of existence that position man as transcending nature. Once again, the acuteness of being a person and the quintessence of personhood, becomes manifest only under the condition of living through solitude. In different words, true anthropology is possible only when humanity turns face to face to itself, that is to its internal world, by disregarding assertions about its grounding in nature and cosmos.

From the point of view of the history of philosophy, anthropological thought was reaching its depths only when human beings experienced an acute sense of loneliness. In the transparency of its non-attunement to the universe and its homelessness in it, humanity turns to itself by posing a question of its own existence and thus making the very process of philosophical enquiry to be the central point of its experience of living.
Roughly speaking, the history of philosophy, as it concerns anthropology, can be permanently divided into two ever permeating and still distinct periods: the first is when humanity comfortably places itself among natural things thus making the world home for itself; the second can be characterized, using Heideggerian language, as homelessness. In the first case humanity considers the whole world as a hierarchical building in which humanity finds its place as its organic although not very significant part. This way of thinking is typical for some apologists of the modern "cosmological perception" of humanity where the whole cosmos is treated not as a hostile and alien reality full of impersonal physical forces, but that harmonized and balanced cosmos which has sense of its existence from itself, regardless of whether humanity exists or not (Primack, Abrams, 2006). Historically it has its root in the Aristotelian view where humanity looses its sense of being a problem for itself, where man is considered to be an object and an "accident", where man appears to itself only as "one of as kind", but not as "I". Here the internal dimension of the subjective perception of existence is abandoned and the place and sense of humanity in the world can only be disclosed through its position in the universe, the outer cosmos. One can say that it is man that is to receive the comprehension of its place in the world and not vice versa, that is the world as receiving its comprehension from the reality of man. The Greek tendency to think of man as positioned in space received its consummation in the Aristotelian world view of concentric heavenly spheres. It is important to stress that for Aristotle his model was not only an intelligible image of reality, it was treated as physically real so that the place of humanity in the cosmos also was very real. Thus this humanity was freed for a while from anxiety of displacement in space of the universe and its homelessness. Man was in his own home - the universe, although with a 
very peculiar position in it between the very large and very small. ${ }^{7}$ Consequently the questions of anthropology and a quest for the sense of existence were not present in such a picture of the world.

The anxiety and the sense of homelessness in this visible world came later when Christianity appropriated Hellenistic philosophy under the rubrics of what is known as Patristic synthesis. The basic change in the picture of the world which Christianity evoked was a conviction that the genuine reality of man is not of this world, so that the visible universe, be it Greek concentric spheres or Biblical flatland, is a temporary shelter for humanity whose destiny is beyond space and time. Christianity not only deprived humanity of the constancy of its cosmic habitation, it brought a new idea in anthropology, that human beings live in between two worlds, so that there is a constant battle between bodily affections and aspirations of the soul. Then is not surprising that St. Augustine, the Latin Father of the fifth century was seriously wrestling with the question of a human being's own nature. The more he was looking into the depth of his own existence, the more the mystery of humanity started to form, pointing to the non-worldly and non-transient sense of the human existence known only to God. The patristic amazement at the mystery of humanity was of a fundamentally different kind in comparison with that of Aristotle, for example. The latter was amazed by human being in the context of his amazement by everything which surrounded him. The Fathers of the Church saw in human beings a creature fundamentally incommensurable with respect to any other creature in the world. In spite of popular ideas of the microcosm they clearly articulated the Divine image in humanity as a main feature of its incommensurability with the rest of creation. Humanity turned out to be on the cross-roads of two worlds so that humanity was deprived of any ultimate sense of attachment, attunement and home. This was the intrinsic conviction of the Christian faith and, as a consequence, there was a lack of any accomplished cosmology and anthropology in the worldly sense. For man by definition was an open-ended creature involving the whole universe into the process of its ongoing incarnation. Any attempt to pin down the human cosmos and to create a home for man, whether this was the naturalistic cosmology or Biblical cosmos, neutralized the acuteness of the main anthropological question on the sense of the human existence. As long as the solitude and uncertainty of existence in between two worlds drives humanity to the realization of its saving telos, the mystery of man, one hopes, will be resolved in the age to come. In this sense Russian Orthodox religious thinkers always treated all secular anthropology and psychology as essentially apophatic, that is attempting to disclose the sense of human existence only in terms of certain (sometimes socially oriented) signifiers which never exhaust the mystery of man, that is that which is signified.

For Russian religious philosophers the question on the meaning of human existence has a logical and philosophical sense only in the context of its relation to the transworldly foundation of this existence, that is in God. However they were eager to explicate why the non-religious consciousness did struggle with the determination of the place of man in the created being. And sometimes they had to use philosophical arguments without any explicit recourse to religious conviction. On the one hand the origin of the sense of solitude and homelessness in the universe (and hence the nonsense of life) had to be explicated. Then there was an impasse of what to do with such a conclusion. Naturalistic anthropology would condemn humanity to being "walking dust" in the universe, such that its existence is already outdated. Here the agony of the human reason reaches its climax because it brings humanity to a dead end. If one 
wills to live one needs to understand "why?" and for what purpose. But these questions are equivalent to an interrogation on the sense of humanity, and there is only one exit from this impasse: to change the method and means of anthropology and stop asking question about the sense of life only in the manner of naturalism. The naturalistic account simply does not provide any desired answer, leaving humanity with the same predicament. The desired anthropology demands transcendence of its naturalistic scope. This inevitably asserts humanity as delivered from the necessities of nature, that is being in possession of an unmasterable freedom from anything in this world from the very moment of its appearance in the incarnate condition. Thus the remedy for solitude and anxiety is freedom. Berdyaev qualifies this as liberation from slavery of the conditioned, from slavery to nature and cosmos, in particular. But this break to the kingdom of freedom requires, first of all, rethinking of the essence of the created existence after the Fall and thus overcoming its limitations and its fringed phenomenality on the level of reason. Only then will enlightened reason be able to realise itself in freedom through practice.

Let us now try to trace those steps which Berdyaev assigns to the process of knowledge that lead to the rise of the sense of solitude and anxiety. He purs a stress on the idea of objectivisation. According to him objectivisation is a natural reaction to what the knowing subject experiences when it attempts to find a ground for himself and his knowledge. In a technical language, knowledge of the world always seeks for a "frame of coordinates", that is the system of reference in order to start its account of existence. In this sense the process of knowing implies a sort of estrangement, understood as creating an external reference point with respect to which the subject can position itself, for as such "the knowing subject is deprived of any interior existence, he does not possess any reference to rely on in being, he exists only in the background and in relation to the objectivisation exercised by him" (Berdyaev 2003[1], p. 53). ${ }^{8}$ But the objectivisation produces objects, that is phenomena with onesided phenomenality, that is those shots of phenomena where all unrepeatedly individual is lost and one can catch only the generic, common and invariant with respect to the circumstances of life. Such a fringed phenomenality with respect to the world is described by Berdyaev as giving an image of the fallen and bewitched world where only phenomena exist but not beings (existents) (Berdyaev 2003[1], p. 62).

Berdyaev, being a religious philosopher, links the very tendency of objectivising the content of knowledge with the conditions of the Fall, that is with that nature of humanity which is distorted by sin. For him all aspects of human activity, including exploring and learning of the universe, are related to the postlapserian condition. Correspondingly the human sense of reality of the universe and man's place in it is affected by that obscurity which had been imposed after the Fall on the initial human faculties. According to the teaching of the Church, before the Fall it was the unity between man and the universe through which the universe was to follow man to its "end", analytically described as the overcoming of divisions (diairesis) in creation (Maximus the Confessor). Man's transgression set nature off course, making it develop in enclosure with itself, isolated and blind, devoid of any telos and doomed to futility. Matter was deprived of its development towards the spirit, it stopped being humanised and being subjected to transfiguration. Humanity did not change its place in creation, but it did change its relation with creation and hence its perception and understanding of the created universe, its sense and meaning as related to the task of mediation which was handed to man and which he did not fulfil. What is characteristic 
for the present condition is that the very process of learning of the external world is the direct consequence of this condition as the necessity of adaptation and biological survival ${ }^{9}$ (as well as a still archetypically present, but obscured, desire to grasp the sense of humanity in the universe). The learning itself is the result of the obstacle that appeared between man and God, a moral division which, in order to be overcome, must be studied. This leads humanity to see the universe in the image of its own moral decline, so that man builds the world in its own image (Clément 1976, pp. 102-103). This is that which Berdyaev calls objectivisation: the world is posed by human subjectivity as some out there, where the intrinsic presence of the human insight is lost. Theologically speaking the learning activities which are pursued by the sciences represent the content of what is meant by the "garments of skin" expressing the human condition after the Fall. This, nevertheless, does not diminish the positive aspects of the "garments of skin", for they were granted to man after the Fall with the purpose not only of physical survival, but of the recreation and renewal of those obscured aspects of being created "in the image of God", which were not destroyed and did not perish entirely. God did not strip man of his reason, as a manifestation of dominion over creation, and it is through the empirical and theoretical acquisition of the outer reality, that is through knowledge and scientific practices, that the world was shaped in a coherent image of the cosmos. However, the most important and constructive positive usage of the human condition in the "garments of skin" comes from the inherent possibility to search through the world involved in flux and mutability for the permanent good and the foundation of the world, that is, as we said before, to preserve an essential dimension of the human condition to transcend the world, that is to resist being physically and spiritually supressed by the immensities of the universe, and to retain its difference and distinction from the world, its centrality to creation through the survived archetypical memory of the initial communion with God.

Once again, using Berdyaev's words, to retrieve one's own divine image (that is to use positively the "garments of skin") the objectivisation must be overcome, that is there must be restored understanding that "the cosmos, mankind, nation, etc., are to be found in human personality as in an individualised universe or microcosm", and that "their falling away from it, their ejection into external reality among objects, is the result of the fall of man, of his subordination to impersonal reality, exteriorisation, and alienation"(Berdyaev 1943, p. 42). ${ }^{10}$ To understand and overcome the inadequacy of objectivisation for understanding the sense and destiny of humanity one must rediscover the interior world of the person. Berdyaev writes: "There is no wholeness, no totality, no universality of any kind outside personality, it exists only within personality; outside that there is only a partial objectivised world"(Berdyaev 1943, p. 42). ${ }^{11}$ But to rediscover personhood behind the objectivised visions of reality means that one can look at the sense of scientific and sociological theories, not only as related to the mutable physical reality, but as those elements of instability and disorder, causing anxiety and despair in human hearts dressed in the "garments of skin", which advance them back to the archetypical state, that is towards that which is, paradoxically, beyond the present and belongs to the age to come. It is through the reversal of the "path of Adam" through spiritual insight into the sense of creation, as the process directed to the future, that the task of relating the universe to its creator, and as a result relating person to the source of its existence in God, can only be fulfilled. In this vision the very process of knowledge, including a scientific one, can be interpreted, if one uses a thought of S. Bulgakov, 
as "the proprietorship of reason in nature, the restoration through labor of the ideal cosmos as an organism of ideas or ideal regularities in which cosmic forces are harmoniously merged and primordial matter and primordial energythe 'foremother' of being - take shape." In this process "science penetrates through the bark and pith of the chaos-cosmos to the ideal cosmos, the cosmos-Sophia" (Bulgakov 2000, p. 195). ${ }^{12}$ But in this case even knowledge of the objectivized world can be interpreted as "a tool for reviving the world, for the victory and self-affirmation of life" (Bulgakov 2000, p. 177) ${ }^{13}$ and hence the person. But if for Berdyaev the process of appropriation of the world is an interior fight for the human person to establish the sense of its existence through the movement away from the objectivized world, for Bulgakov a similar process would have a different objective as the transformation of the universe into the "all-organism of humanity" through the unbounded incarnation of humanity in the universe through its knowledge and exploration. The universe is to be humanized rather than vice versa, that is humanity assimilated into world and nature.

\section{Humanity's position in the universe and the paradox of human subjectivity}

What is common for many Russian philosophers is their formulation of the paradoxical condition of humanity in the universe which naturally appears in the objectivised scheme of things. The sense of this paradox can be easily grasped on cosmographic grounds. Indeed, along the same sentiments which tortured Pascal, according to modern cosmology human beings occupy practically an infinitely small part of the universe while being able to predicate the universe as actually infinite. The paradox is obvious: the finite, insignificant embodied human agencies in the vast universe articulate the entire space-time span of the universe from a point-like position. The ambivalence of humanity's position in the universe can be expressed in terms of a famous philosophical paradox asserting that while being in the universe, humanity is not of the universe. The dualism of the human position in the world, which is present in this paradox, constitutes the inherent feature of any discourse related to the global features of the world which has to reconcile the locality and contingency of the cosmic position of humanity with its abilities to transcend this locality and encompass in theory the universe as a whole. ${ }^{14}$

Certainly for Russian philosophers the content of this paradox was not limited simply to humanity's spatial insignificance in the universe. They also experienced this paradox as a drama of the human freedom squeezed by the conditions of physical embodiment leading to the fear of death and enslavement to this fear, according to Berdyaev (Berdyaev 1943, p. 252). This paradox exhibited the limits on the exercise of the ultimate moral law, originating in the Divine, in the conditions of the world after the Fall. As it has been formulated by Kant, there is a difference in appreciation of the things which fill the human mind with "the starry heavens above and the moral law within" (Kant 1959, p. 260). One can say that the content of the paradox explicates the drama of the human condition after the Fall. The ambivalence between appreciation of the reality of existence on the one hand, and the incessant and saturating presence of death as the end of life on the other hand, explicates the sense of the hidden impetus in the restoration of the fullness of the Divine image in humanity lost after the Fall.

One must point out that, historically, the paradox was formulated by early Christian theologians in the context of their teaching on the Divine image in man. Here is a passage from St. Gregory the Theologian (Naziansus) with a characteristic formulation of the paradox: "...the 
Artificier of the universe, the Logos, created man as a single living creature from both elements, that is to say from the nature of both the visible and the invisible worlds." ${ }^{\prime 15}$. In St. Maximus the Confessor the paradox was interpreted in the context of faith in God who created man in his own image and likeness, so that initially man was "like" God, that is he was "all in all". C.f. (Col. 3:11). For example, Maximus described this presence of man in all things in terms of a potential unity of all creation, which was to be realised by man as originally created: “...man was introduced last among existent things, as the natural bond mediating between the extremes of the whole through his own parts, and bringing into unity in his own person those things which are by nature far distant from each other..."16. Man was created in order to mediate between all divisions in creation, for example between the sensible (visible) and intelligible (invisible); Maximus writes: "As a compound of soul and body he [man] is limited essentially by intelligible and sensible realities, while at the same time he himself defines [articulates] these realities through his capacity to apprehend intellectually and perceive with his senses." ${ }^{17}$

Russian religious thought contributed to the formulation of this paradox by discussing the problem of the place of man in creation and his destiny. Let us give a brief account of these formulations in order to accentuate the problem with which Russian philosophers were wrestling. If we start by quoiting Vladimir Soloviov's Readings on Godmanhood, then, for him, the ambivalence in humanity's position in being can simply be expressed as the dichotomy between the internal freedom of man's spirit and, at the same time, its insignificance as a physical being in the great scheme of things:

"Modern man realises himself as free inside, above all that is external to him, and of any foundation which is independent from him. He affirms himself as being the centre of all; however, in reality, he is an infinitely little point in the world's circumference... On the one hand man is an existent being with an undoubted significance, with unconditional rights and demands, whereas the same man is only a limited and transient phenomenon, a fact among other facts, bounded by and dependent on them. And not only a particular man, but the whole mankind..." (Soloviev 1989, p. 21). ${ }^{18}$

In a different passage Soloviev articulates this ambivalence in a more dramatic form: humanity manifests in itself the unity of the opposition between the visible (empirical) world and that which is beyond not only the visible, but beyond the created:

"Man comprises in himself all possible oppositions, all of which are reduced to one great opposition between the unconditional and conditional, or between the absolute and eternal being, and a transient phenomenon, an illusion. Man is deity and nothing at the same time" (Soloviev 1989, p. 113). ${ }^{19}$

Here is another characteristic insight from N. Berdyaev:

"There are in personality natural foundation principles which are linked with the cosmic cycle. But the personal in man is of a different extraction and quality which always denotes a break with natural necessity... Man as personality is not part of nature, he has within him the image of God. There is nature in man, but he is not nature. Man is a microcosm and therefore he is not part of the cosmos" (Berdyaev 1943, pp. 94-95) ${ }^{20}$; hence "the place of man in the natural world is tragic. Man is not only an object in this world, first of all he is subject which cannot be deduced from an object. Given this, the relation of man to cosmos is determined through him being microcosm; he enfolds cosmos and history...Through the spiritual in him, man is not subordinated to nature and independent of it although natural forces can kill 
him...He is a slave of nature and he is its lord" (Berdyaev 2003[2], p. 588). ${ }^{21}$

This can be paralleled with Fr. Pavel Florensky, according to whom "nature and man are both infinite. And it is because of being infinite, that they are commensurable and can be parts of each other...Man is in the world, but man is complex to the same extent as the world. The world is in man, but the world is also as complex as man" (Florensky 1994, p. 186) 22. "Man is the recapitulation of the world, its summary; the world is the disclosure of man, its projection"(Florensky 1994, p. 187). ${ }^{23}$ Sergei Bulgakov contributed to the same stream of thought: "On the one hand, man is potentially all, the potential centre of the anthropo-cosmos, which, although, not yet realised but is being realised, on the other hand man is the product of this world, of the empirical" (Bulgakov 2000, p. 146). ${ }^{24}$

The implicit presence of the paradox in all objectivistic affirmations of the universe reflects the intrinsic split between the two different modes of intentionality. The self-awareness of its own transcending nature happens when the intentionality has to deploy its means to cope with the constraints and pressures of the outer world (embodiment, for example). The more the universe attempts to "crush human existence under the weight of astronomical facts", the more the egocentric intentionality prevails as a measure of resistance to it. The more the pressure of the outer world relaxes, the more the same intentionality relaxes and the transcendental "I" looses itself in the outer things. Thus the constraints of the constitution of the outer world which escape clear-cut definitions and visibility constitute the very intentionality to the extent that it cannot fully cope with these constraints. Then one can see that the paradox of human subjectivity is not simply an epistemological conundrum, it reflects a genuine ambiguity or bipolarity of human beings, which must be existentially balanced.
In this respect one can quote $\mathrm{S}$. Frank, who, by formulating the existential dichotomy of human existence, made a valuable comment that any attempt to remove this dichotomy or explain it away leads to a distorted anthropology and hence cosmology:

"Through his body and carnal life, and external layer of his mind determined by its connection with the body, man in himself forms part - a subordinate and insignificant part - of the objective world....Through his depths through the kernel or root of his being, and in this sense through his true essence - he belongs to the transcendent primary reality.... Man thus has a dual nature, and every theory of life which fails to account for both aspects of his being is bound to be inadequate. ..The structure of our being is complex and antinomic, and all artificial simplification distorts it" (Frank 1965, p. 34$35) .{ }^{25}$

Correspondingly the dialogue between theology and science, the problem of faith and knowledge by the virtue of its factual existence manifest and explicate the complex life of man as being split in its intentionalities between the mundane things of the world and their underlying foundation, including the foundation of the very consciousness which is responsible for the facticity of both, namely theology and science.

\section{From the paradox of subjectivity to personhood}

The paradox of human subjectivity in the universe can be explicated as pointing towards the different positions human subjectivity can adopt with respect to the ontology of being. On the one hand there is an explicit treatment of the world in terms of thinghood, that is, in terms of things pregiven in order to be recognised by thinking consciousness. In this sense the universe pre-exists as substance and the ultimate ontology of being is thought to be the ontology 
of this substance. Then the facticity of human beings in the universe is treated as the variation of this substance. In this case humanity, being a part of the universe, stands in a moral opposition to it in the sense that it experiences fear that the laws of the universe at some stage can remove the phenomenon of humankind from its surface. On the other hand there is a different intuition which can be described as the living presence of personhood in all articulations of the universe. In other words, things which are out there, objects and entities in the universe appear not as an external and hostile environment but as the manifestation of the living presence of human subjectivity in the universe which actually makes all these things beings. The making of the universe must not be understood as manufacturing things from some pre-given material, but rather as creating things in a rather different sense. By making an artificial object from a pregiven material, the underlying substance is subordinated, controlled and dominated by individualised thinking. In some sense a human being, who is involved in this kind of making, is itself transformed into a thing which acts with respect to another thing. But man as a thing is not man as a person, and to create in the sense of personhood means not to dominate the pregiven, but to create such an ontological situation where all so called things acquire the "presence" relevant to the totality of existence understood not in terms of substance but in terms of hypostasis. Humanity itself becomes present and manifestthrough transferring its hypostasis to being. ${ }^{26}$ This hypostasis is not something which 'pre-exists' in substance or in nature, it is not an impersonal combination of the worldly elements or platonic numbers, but the centre and the ultimate beginning of all articulated existence.

The paradox of human subjectivity explicates the insufficiency of the scientific world-view (which functions in the natural attitude and leads to what Berdyaev called "objectification") in appropriating the problem of personhood. For example, in modern physics and cosmology, there is the grandeur of the world as it is understood by physics: it deals with particles, fields, spacetime, planets and galaxies, but there is no place for human subjectivity, for the only thing physics can speculate about is the physico-biological functioning of human bodies. Physics does not attempt to understand human consciousness and its hypostatic origin as personhood. Physics is the product of thinking individuals whose consciousness was directed to the world, but the very fact that physics is possible at all, that is its sheer facticity, as the ability to articulate the universe, is not understood and even not attempted to be understood. This happens because personal characteristics of those who create the physical picture of the world are remarkably missing from the very result of their activity. It is clear that personhood must be present behind the living presence of the world, the presence which is the result of personhood's creativity; at the same time this personhood cannot be made explicit in its presence. One can say that personhood, while being tacitly present behind the works of its own creation as the source of this creativity, is explicitly absent from its own creation. The picture of the universe is the manifestation of personal presence in the universe, but those persons, who created the picture, are not explicitly found in it. Science itself, by virtue of its existence, manifests the presence of persons in the universe, but in its outward content it creates conditions for the unconcealment of being in its theories, which takes place at the expense of concealment of persons.

The concealment of personhood can be easily illustrated by pointing out that the whole edifice of science, while being produced by particular historical persons represents an effort of anonymous and collective subjectivity which 
is not interested in contingent incarnations of this subjectivity in historical beings. In spite of the fact that a scientist works in a particular historical situation which forms the immediate existential horizon, their activity is directed toward the infinite horizon of omni- and trans-temporal truth, that truth which is accessible in principle to everyone and hence this truth transcends the relativity of any truths achieved in a historical situation connected with a particular person. But this omni-temporal truth, as an "infinite" task, is not achievable by one particular scientist. This or that scientist should participate in a collective activity of the many by submitting his individuality, to the interests of the open-ended collective of scientists which outlines the tradition in which all scientific accomplishments acquire a certain sense. It is in this sense that the presence of a particular scientist who advances a general view of reality is important only as a contributing factor to the overall tradition. Paradoxically a particular historical presence of this scientist (who is a person) is crucial for the advance to be made; however his or her personality is not important in the context of the knowledge achieved, the knowledge which since its first articulation by a scientist and its appropriation by a community enters so to speak the realm of a-temporal ideas to which everyone has access. One observes here an interesting transformation of personal knowledge into an a-personal and anonymous compendium of knowledge whose ultimate subject is the depersonalised, that is anonymous, transcendental subjectivity. It is now clear why, when a scientific fact or a theory are "downloaded" on a routine basis from the compendium of ideas, it is unnecessary to enter communion with a person who brought them into existence and who is, in a way, still present behind them. The memory of this person will enter the discourse only as labels of past historical discoveries and it is this that happens in science.
At the same time, in order to understand science as an overall process, one should study its history, not as a chain of contingent facts and persons, but as the open-ended unfolding horizon of meanings which simultaneously serves as the delimiter of science. To understand science in a profound philosophical sense one must gain an insight into the founding action which originally instituted it, into the process by which its concepts were created, and into the original spiritual motives of its creation. However these spiritual motives are not explicitly present to scientific reason because personhood as an existential centre of these motives does not show itself to science: it is present in absence. It is interesting to mention that while in their very genesis theories and ideas contain the traces of personal agencies which created them, their presence is of a different kind if one compares it with the work of art. In art, when one enjoys painting or listens to music one perceives the presence of an artist or composer in their actual absence: they are present only because they are absent. In every work of art a person manifests itself in its fundamentally irreducible originality and distinctiveness with respect to all community, including that one of artists themselves. Each work of art is the end in itself which cannot be simply used in order to create a consecutive piece of art. ${ }^{27}$ It is in this sense that the person is always present behind this piece of art and this person is essentially historical and concrete. The understanding of a masterpiece is not that algorithmic way of downloading scientific ideas from the already pre-existing world of articulated ideas; on the contrary the approach to a piece of art requires a personal effort, which cannot be taught and explained unless a direct communion with the "mind" of the artist is established.

The absence of human consciousness and personhood from the objectivised picture of the world was in the history of thought qualified as the 
result of an extreme realisation of the rational ideal as the hegemony of discursive reason. Rationalism appropriates any personal contribution dissolving the presence of any personal insight and achievement into an impersonal ocean of ideas. Indeed, in order to formulate an idea there must be a person. But what is left from this person when the idea is formulated and inserted in the already articulated part of the world of ideas, is just a mode of transcendental subjectivity which does not need any hypostatic specification. By working through logic, induction and dissection applied to things this discursive mind manifests itself in its natural attitude. One can qualify the natural attitude as such transformation of the totality of existence perceived through personhood, which corresponds to the disintegration of the living and united presence into divisions among outer things allegedly existing independently and prior to events of personhood. In simple words, the natural attitude promotes an ideal of objectivity, that is the phenomenality of objects. It is in this sense that in the natural attitude the presence of persons is not seen: they are still in place, but they do not show themselves. But it is exactly through the absence of personhood in science that the philosophical and theological reason can anticipate its implicit presence. The very fact that science is not able to account for personhood shows in fact the only possible condition of its functioning, namely the presence in absence of personhood. In a way, the objectification in the style of Berdyaev "mortifies" human beings ${ }^{28}$ and reduces them to impersonal physico-biological organisms in order to affirm their presence by means of observation and rational induction. But personhood as existential event escapes any objectivistic grasp by transcending either materialistic definitions or idealistic beliefs. Personhood manifests itself as an absolute freedom which cannot be subjected to any constraints of the pregiven matter or categories of thinking. This is the reason why it is impossible to define personhood in the way one defines things. Things can be defined because they can be possessed, but it is impossible to possess persons and this is the reason why personhood escapes any rational definition.

For many Russian philosophers who lived and worked at the end of the $19^{\text {th }}$ and beginning of the $20^{\text {th }}$ century, the predicament of the objectivising tendencies of the natural sciences was associated with the expansion of a mechanistic trend in philosophy. According to the mechanistic view of the world, the universe follows some blind laws of nature in which human freedom is excluded and thus the very human existence is devalued and subjected to the necessities of the natural existence. In the realm of spirit, if a scientific worldview becomes a dominant factor in social development, it leads to the loss of religious feeling about the significance of humanity in the universe, and, later, to the loss of faith in God. This is the reason why Nikolai Berdyaev formulated an extreme view that truth can hardly be found along the lines of a scientific search. One has to "overcome" the scientific approach to knowledge of the world by means of its factual denial, in favour of searching for the foundations of being in religious philosophy and, in the long run, by means of developing cognitive faculties leading to mystical feeling and "mystical thinking". Berdyaev claimed the primacy of faith before knowledge: knowledge and science in its base assume faith. ${ }^{29}$ However, that faith in reality which is inev itable in scientific objective research must not be confused with faith in a personal God (Berdyaev 1989, pp. 51-52). Based on this thought, Berdyaev ultimately draws a borderline between science and religion. He has to admit, however, that the truths of science cannot contradict the wholeness of Truth (Berdyaev 1953, p. 44). Thus Berdyaev's negative attitude to the scientific way of knowing was based on his rejection of the self-sufficiency of science and, as a 
result, on his conviction that one should turn to the foundations of science, whose understanding was lost in the process of the expansion of mechanistic ideology. The search for these foundations must lead an attentive mind to religious philosophy and religion as such. Berdyaev argues for the restoration of the dignity of the person who is lost in the mechanistic universe and enslaved by the mechanism of nature. The liberation of persons means the overcoming of their slavery to nature; this can only be achieved on the ways of religious freedom, which are available to persons as those centres of active and creative self-articulation of the world through which the very science becomes possible (Berdyaev 1989, p. 65), (Berdyaev 1943, p. 96). Berdyaev insists that the mystery of human personhood is related to its dual nature: on the one hand to its intrinsic natural (physical) necessity, and on the other hand to its ability to transcend the limits of this nature as being an image and likeness of the highest being, as a microcosm before whom the whole majesty of nature stands (Berdyaev 1989, c. 294-96), (Berdyaev 1943, p. 81). One must add to this an emphatic apology of Berdyaev for the uniqueness of person and its origination from the absolute freedom. For example: "Personality is not a part and cannot be a part in relation to any kind of whole, not even to an immediate whole, or to the entire world....Personality is not made up of parts, it is not an aggregate, not a composition, it is a primary whole" (Berdyaev 1943, pp. 21, $23)^{30}$; or "the secret of the existence of personality lies in its absolute irreplaceability, its happening but once, its uniqueness, its incomparableness" (Berdyaev 1943, p. 23) 31 ; or "personality is connected with freedom from the determinism of nature, it is independent of the mechanism of nature" (Berdyaev 1943, p. 34). ${ }^{32}$ Berdyaev blames the science of his time for not being able to realise the depth of the problem of humanity and, according to him, this is why one must ascend to religious philosophy, which is the only means that can handle the problem of human personhood. Indeed, according to Berdyaev, "personality is not born of the family and cosmic process, not born of father and mother, it emanates from God, it makes an appearance from another world" (Berdyaev 1943, p. 36). ${ }^{33}$

In a way, all definitions of personhood formulated by the Russian philosophers have, so to speak, an apophatic character. They define personhood in terms of that which this personhood is not. And if one generalizes these definitions philosophically, one can state that personhood escapes definitions in terms of a rationality of objects: it is that intrinsic condition of subjectivity that cannot be alienated and detached from the very acts of knowing consciousness as such. However personhood manifests those feature of consciousness which as such are given to a subject as primary conditions of its existence at all. That is personhood characterizes not simply a dynamic of conscious life, but its ontology. The question that remains is whether personhood can be characterized constructively in terms of those definitions which themselves do not produce an infinite hermeneutics. As we will see this can be done only by employing a theological modus of cognition and reflection positioning personhood within the scope of such notions as freedom and God. However, the ascent to the theological comprehension of personhood can be performed, not through an appeal to religious faith and dogma, but through a careful philosophical insight, based in a phenomenological suspension of any judgments about objectivity in the positive sciences and bringing their alleged object of study in the interior of the human subjectivity.

Since the essence of personhood cannot be exhausted by discursive reason it is obvious that scientific methods are fundamentally insufficient in order to deal with the problem of personhood. However, this does not mean 
that persons disappear from scientific discourse completely; on the contrary, they reveal their inescapable presence in a rather dramatic way. This happens because humanity as personhood is not content with the presence of any beings in the world as they are given to it empirically and studied only scientifically. Humanity attempts to understand the underlying meaning of things not only through their "nature", in the phenomenality of objects, but through the purposes and ends of these beings as they stand with respect to the place and goals of humanity in creation. In other words, the underlying impetus of the objective representation of nature is still purely subjective, for it originates in the anxieties of existence with their questions of "where we come from and where we go?" as well as "what is the meaning of all that surrounds us?" Definitely, the response to such a question cannot be expressed physically and biologically; ultimately it is sustained by humanity's ideals and religious aspirations, which portray man as the crown of creation made in the image of God. This is the reason why in a God-like fashion humanity wants to recognise its own being not according to its compelling givenness, but as results of humanity's free will ${ }^{34}$, that is according to its major dimension of being made in the image of God, that is freedom. Also it is by subjugating that truth which is gained on the grounds of the scientific, to the desire for the truth of existence originating in communion with the hypostatic archetype of the image, that humanity exhibits its own hypostatic essence, that is its personhood. Personhood remains an ideal of life aiming to remove all constraints on the confession of love while being doomed to its own incapacity to achieve truly personal life. As a resistance and protest against such an incapacity humanity does not want to be manipulated through circumscribability and individualisation which are inherent in spatiotemporal forms of creation. Correspondingly human persons long for the truth of existence which is in this world but not of this world. This longing forms spiritual motives of humanity and points toward the telos of all creaturehood, in which the paradox of personal existence will be finally resolved. This eschatological sentiment, in fact, implies that the actual and the only real contradiction in the world's being, that is, "the contradiction of self-consciousness and life in being of human person", cannot be removed or solved in physical time. As V. Nesmelov writes even "if the world would become known to man through development of the positive sciences, the factual contradiction of man's being still will not be removed and hence the making sense of this contradiction will constitute for him a great mystery of being" (Nesmelov 1905, p. 242). ${ }^{35}$

The accentuation of personhood as an escape from the circumscribability of the human phenomenon through scientific rationalism, de facto implies a phenomenological reduction leading to rediscovery of the life-world as the core and basis of the indwelling in the world. This rediscovery, as a phenomenological reversal, means the inclusion of the objectivized world inside man's subjectivity. As expressed by N. Berdyaev, "man ought to rebel against the slavery of history not for the sake of finding isolation within its own self, but in order to take all history into his own infinite subjectivity, in which the world is part of man" (Berdyaev 1943, p. 267). ${ }^{36}$ The phenomenological reduction here is the suspension of the naivety of the primacy of the objective world as uncontrollable history, and acceptance of this history as unfolding according to the teleology of the human spirit. Such a reduction in turn would imply the return to the study of the foundations of the sciences as intrinsically anthropic enterprises. Thus the disappearance of personhood in the scientific picture of the world will be subjected to a phenomenological reversal in order to explicate 
those intentionalities of human subjectivity which led to the development of contemporary science, and, behind these intentionalities, real living persons who initiated this development. This shift in the attitude of treating the sciences as not delivering passive reflections upon the realities of the surrounding world, but as those activities of human subjectivity which attempt to constitute personhood, can in turn take place only in the paradoxical condition of personhood discussed above. Viktor Nesmelov describes this situation in the following words: “....any man's attempt to fulfill the natural content of his personhood on the ways of the physical development of life necessarily contains in itself an unsolvable intrinsic contradiction and naturally does not lead man to anything" (Nesmelov 1905, p. 243). ${ }^{37}$ Indeed, if one considers the development of persons physically and biologically, that is through processes uncovered by the sciences, then one deals only with the aspects of their embodiment, rather than the integrity of the balance between the physical and the properly intellectual and spiritual. However, as Nesmelov continues, "with all respect to its great success in the cultural transformation of reality man remains... no more than a simple thing in the world that emerges and decays only because of the necessary laws of physical nature and therefore exists under the form of personhood without understanding the sense and meaning of this existence" (Nesmelov 1905, p. 243). ${ }^{38}$ The sciences as such manifest the existence of persons as their creators through the sheer complexity of scientific theories. However, why the sciences are possible at all, remains incomprehensible to the same extent as the sense and meaning of existence of personhood. Correspondingly if the attitude to the sciences changes, that is if they are approached not from the point of view of the content of their theories and alleged references to the physical world, but treated as hermeneutical tools for understanding humanity itself (using the human image of the universe as a mirror through which human subjectivity and persons constitute themselves), the sense of the sciences can be reversed: they can now be seen as those activities of the human self that through its outward look establishes itself and brings out (according to its free will) personhood to its explicit manifestation. The phenomenological reversal of such constructs as the universe (which served the naturally oriented mind to be an ultimate objective background of all facticity of life), acquires a status of a structure of transcendental consciousness whose incarnate facticity follows the logic of existential events and cannot be reduced to anything that is more primary than these events. If, in the natural attitude, science affirms the explicit presence of the universe at the expense of disappearance of personhood, in the philosophical attitude the universe, as an intentional correlate of human subjectivity, does not possess qualities of "out there", that is of presence as any other thing. The universe in all its entirety is en-hypostasised by human beings; but since the entirety of the universe is not available to our grasp, this very en-hypostasisation turns out to be no more than the manifestation of the universe's presence but in its actual absence. This result is not surprising, for as personhood escapes complete definition by reason, manifesting itself only through its tacit presence, the universe, being de facto a mirror of the human reason also escapes complete definition.

\section{Personhood and Overcoming of Solitude}

Russian philosophers understood well that no accomplished definition of personhood is possible, and that the problems and contradictions in the foundation of any definitions would be explicit characteristics of that which personhood is. According to V. Nesmelov, the main ambiguity 
of personal existence originates from the limited being of man and the human image of the unconditional being: "all particular contradictions of thought and life arise from man's aspiration to fulfil the ideal image of the unconditional in the necessary boundaries of the external conditions" (Nesmelov 1905, p. 246) ${ }^{39}$. However, since this aspiration cannot be accomplished, the main ambiguity of man's being not only cannot be removed but, on the contrary, is revealed to him ever more clearly as eternally irremovable, because it is along this way that man realizes its position in the world as a thing among other things. The image of the unconditional being thus constitutes the image of man as an unconditional essence in spite of the fact that it remains a simple thing in the physical world. The assertion of the personhood of man thus becomes a strange procedure from an epistemological and spiritual point of view, because in its affirmation of the affinity to the absolute and unconditional being humans understand that they can never achieve the state of existence of this unconditional being. But this strangeness exactly becomes a basic characteristic of personhood and its problematic status. Correspondingly, to aspire to personhood in thought and actual life, means, de facto, to deal with its mystery, which at the same time, is the mystery of being in general. Then the unconditional character of personhood, being placed in constant contradiction with conditional being in the world, evokes thinking of the Divine (Nesmelov 1905, p. 261). Man as a person can only be an unconditional being: this is the "fact" which man knows through knowing himself. The person asserts itself as a free agent of its own volition and this mode of being is called by Nesmelov as absolute and unconditional: "only an unconditional being can be a person; every man is directly aware of this and truly knows this through knowing of himself" (Nesmelov 1905 , p. 264 $)^{40}$. The human person represents that link, or pole of being, where the unconditional and conditional meet. Here Nesmelov again points to the vanity of all scientific attempts to "explain" personhood in its incarnate conditions. In its displayed givenness it can be studied, but the fact of its existence, as a real fact, can only be interpreted through the help of the Bible, in which the existence of man is posed as a fact of the relationship between God and the world. It is the mystery of the facticity of personal beings that leads all philosophy and science to the idea of the free creation of persons by God, persons which sustain that mode of being from within which the disclosure and manifestation of the universe take place. As Nesmelov writes:

"But existing as a person and, at the same time, as an ordinary thing of the physical world linked necessarily to the mechanism of external conditions, man is not an unconditional being, but only expresses in itself the real link between conditional and unconditional being... If scientific thought had not denied this mysterious fact through its pseudo-scientific explanations, but had truly contemplated it as an incomprehensible fact of being, perhaps long ago scientific thought would have come to the Biblical vision of humanity as made in the image of God. This could be possible because the existence of man as an image of Absolute Being can be established strictly scientifically and independently of the Bible just from the psychological analysis of the nature and content of human person, so that one can appeal to the Bible not with the purpose of extracting from it this very doctrine, but only in order to find in it the explanation of the real fact. Both the objective being of God, as well as true knowledge of his nature are directly given to man through the real being and natural content of its own personhood. But why and how is human person as the real image of God possible within conditional being, - this we do not know and cannot know, so that the Bible tells us about the 
creation of man by the will of God" (Nesmelov 1905, pp. 264-65). ${ }^{41}$

Let us accentuate the important aspect of Nesmelov's thought: the very assertion of personhood as a sheer fact while other facts take place from within human life, which reflects upon itself and finds in itself the irreducible presence of some absoluteness and freedom which are not determined by the external conditions. The presence of the absolute in human consciousness is a fact. The usage of the language of fact (in contradistinction, for example with the language of objects) position the existence of persons in the category of events, whose phenomenality can never be exhausted through the representation of objects and represents that puzzle for human consciousness which this consciousness cannot comprehend but is itself constituted by this puzzle. Put bluntly, personhood is given to human persons themselves as such a phenomenon, which can never be presented in the phenomenality of objects, because personhood entails the image of the infinite absolute being that also can not be represented in the phenomenality of objects. Nesmelov insists that the fact of existence of man, the reality of its very being, de facto, justifies the idea of God, and that the two-fold hypostatic constitution of man, justifies knowledge of God (Nesmelov 1905, p. 266). In a way, the inherent sense of the Divine which justifies religious experience, faith, theology, as well as all other modes of the human activity, proceeds from the fact of life, that is the existence of human persons. But the fact of the existence of persons is inferred by man exactly because personhood cannot be realised under the form of representation. Person poses itself as free with regard to the cause and goal of its actions, so that it affirms itself not through the physical law of mechanical necessity, but through the trans-sensible principle of the reasonable foundation. Correspondingly the trans-sensible being is known to man through the immediate consciousness of being and the content of his own personhood (Nesmelov 1905, p. 268): "In knowledge of ourselves we know truly, that although our own person exists only in the necessary conditions of the physical world, by its own nature it manifests not the world, but the true nature of the very Infinite and Unconditional, because the infinite and unconditional is free being for itself, but free being for itself is and can be only being of the self-existing Person" (Nesmelov 1905, p. 269). ${ }^{42}$

The question then is how the meaning of personhood can be explicated in, so to speak, "practical" terms. In other words, what can be an existential objective of human beings in order to realise their personhood, that is the image of the unconditional and absolute, in the conditions of necessities of nature. Nesmelov points towards moral consciousness as that characteristic of spiritual and personal existence which leads man not to the idea and knowledge of life as the good, but life as truth. Nesmelov writes:

"What is expressed through the content of the moral consciousness is exactly a natural selfdetermination of a human person in the conditions of its physical existence. It is that moral for man which must be fulfilled by him; but man must fulfill that which is truly human, then it is that truly human which expresses by itself the true nature of the human person independently of the conditions, interests and goals of its physical existence" (Nesmelov 1905, p. 287). ${ }^{43}$

Moral consciousness is that one which seeks the determination of the sense of personal existence independently of the natural conditions of existence of this person in the physical universe. However, it is exactly this real living in the world in accordance with moral consciousness as such, that becomes impossible; it remains no more than a representation of the moral consciousness: “...the point is exactly that, that true life whose existence man grasps through moral consciousness, in fact, 
cannot be realized because man exists not only as a free agent in the world, but as a simple thing of the world, a thing which is subordinated to the general laws of the physical existence" (Nesmelov 1905, pp. 287-88). ${ }^{44}$

This negative assertion of man's incapacity to fulfill his humanness according to the ideal of moral consciousness has, so to speak, a positive dimension, for it is through the impossibility of achieving the ideal of moral consciousness and humanness as free from the conditions of the physical, that human person asserts itself as an image of the absolute personal being (Cf. Nesmelov 1905, pp. 288). On a level of practical existence, however, the gap between the ideal and desirable on the one hand, and the impossibility of achieving freedom from the necessities of the world on the other hand, creates a feeling of ontological solitude that remains an inerasable sign of the typically human existence. The presence of this sign and the possibility of its articulation and manifestation both point towards the image of the absolute and unconditional in the human person. Nesmelov concludes that "the ultimate result of the science of man is the irresolvable mystery of his existence; how could man appear in the world whereas by the essence of his personhood he denies the world, and as such he is in turn denied by the world?" (Nesmelov 1905, p. 372). ${ }^{45}$ In a different pasaage Nesmelov reasserts this point: "all man's deliberate virtue, in fact, rests only in his disdain of the world and its denial, and not at all in his desire to unfold in it and by its means the truth of the moral order and through this unfolding to reflect in the world the life of the Absolute Person" (Nesmelov 1905, p. 391$){ }^{46}$

Correspondingly, if such a denial of the world is effected, man cannot have any meaning in this world and thus involuntarily mentally displaces himself into a different unknown world, still with no hope to reach that world existentially, remaining under the spell of its overwhelming lure, distracting himself from the humble and dispassionate acceptance of the gift of life on this planet.

In the reciprocal denial of the world by man, and man by the world, the sense of the non-attunement and homelessness, as well as of ontological solitude, is constituted in man with no hope to find consolation either in this world or in any imaginable realm of the created. The search for the hope of finding the sense of existence is then transferred to the realm of that absolute and unconditional which reveals itself vividly in the anxieties of existence. But even if God comes to mind as a savoir and guarantor of the ultimate sense of existence, in its physical life man does not reach its destined place, so that his faith in that he occupies a very selected and special place in creation remains only a matter of his eschatological conviction with no possible justification on the grounds of reason. Reason becomes redundant as a practical tool of solving the mystery of the human existence so that faith has to replace it but not as an epistemological sentiment, but as a way of existence as such.

The denial of the world on the grounds of asserting personhood effectively means that when man talks about person he intuits and contemplates his own personal existence as something which cannot be formalised and expressed in the phenomenality of objects. In this sense the very assertion of personhood as an exclusively human feature immediately positions humanity beyond the world of objects. But, remaining a thing among other things, man is disturbed by this strange contradiction that not everything that is in man can be known and understood on the grounds of personal reason. There is something in the human condition which escapes all understanding and thus effectively retaining the very phenomenon of humanity to be unknown to man himself. In fact the very denial 
of the world means not less than the impossibility to know the world and its meaning in the condition of not being able to know what is man. The mystery of the human existence and its ambiguous standing in the world, as it was explicated by the Russian philosophers, ultimately means that man is brought into existence exactly subject to the condition that he cannot be known to himself. In a contemporary parlance it is exactly this paradox that constitutes man's phenomenality consisting in that man can be shown to himself in such a way that he cannot be known to himself.

Definitely Russian religious philosophers were not the first ones who had to reaffirm the premise of the unknowability of man to himself. If one refers to the Biblical account of creation of man in Genesis, one finds that Adam is given a privilege of naming, understanding and dominating the world of all non-living and living things. However the first man-Adam exercises this privilege only upon the animals, never upon God, and, what is more interesting, not upon himself. The fact that any attempt to define God always fails can easily be conceived by remembering that God is the Creator of all, so that he cannot be comprehended by man, that is by a creature, who is, ontologically distant from God, and for whom the mystery of his own creation is existentially and epistemologically inaccessible. The question is why man does not exercise the privilege of naming and hence comprehending himself. The answer comes from the detailed Biblical account of what is man and how he was created: among all living creatures man alone was created not according to various kinds of living creatures (including man himself) but "in the image" and "after the likeness" of God (Gen. 1:24, 26). Man remains unnamable, that is not being able to be defined in terms of other things and species, that is in terms of objects which fall under a sort of classification, because he is created, that is formed and constituted in the image of God who admits no creaturely image, and whose proper names are beyond any denomination. Man as image of the Personal God, being a hypostatic creature, is infinitely distant from anything which he names and articulates. Thus man resembles nothing in creation, because he resembles God whose proper names are unknown. God being incomprehensible and beyond any measure with the created, transfers this proper quality to man who thus resembles him by having the privilege of God's incomprehensibility. This means that manhood exceeds any possible definition, be it anthropological or psychological definitions, or any classification of human beings among other beings. Man appears to himself and to the other immediately within the image of the Absolute and Unconditioned God who surpasses all manifestations of his light to man. Incomprehensibility of man as incapacity of his own understanding makes him invisible, not because of the lack of light of the Divine in him, but because of its insurmountable excess originating from God himself. Man is thus radically separated from every other being in the world by a definitive difference that is not any longer only ontological ${ }^{47}$, but iconic. This intuition can be found in St. Gregory of Nyssa:

"The image [eikon] is properly an image [eikon] so long as it fails in none of those attributes which we perceive in the archetype ... therefore, since one of the attributes we contemplate in the Divine nature is incomprehensibility of essence, it is clearly necessary that in this point the image [eikon] should be able to show its imitation of the archetype. For if, while the archetype transcends comprehension, the nature of the image [eikon] were comprehended, the contrary character of the attributes we behold in them would prove the defect of the image [eikon]; but since the nature of our mind, which is the likeness [eikon] of the Creator, evades our knowledge, it has an accurate resemblance to the superior nature, figuring by 
its own unknowableness the incomprehensible Nature." ${ }^{248}$

To know man thus requires referring them to the incomprehensible God and thus by grounding man's incomprehensibility in the Incomprehensible, by virtue of man's being its image and likeness. St. Augustine, makes a similar observation that man can be known only by God: "yet there is something of the human person which is unknown even to the 'spirit of man which is in him.' But you, Lord, know everything about the human person; for you made humanity". If man realizes this fact of its own incomprehensibility, its own ignorance of himself is to be transformed through confession towards God's knowledge of myself: "Accordingly, let me confess what I know of myself. Let me confess too what I do not know of myself. For what I know of myself I know because you grant me light, and what I do not know of myself, I do not know until such time as my darkness becomes 'like noonday' before your face. ${ }^{, 49}$ Man as a thing of the world is infinitely distant from man as a hypostasis of the universe. It is this intrinsic split in his consciousness as an infinite difference of man from himself that he cannot comprehend, and which, probably he should not comprehend. ${ }^{50}$

Their own incomprehensibility tells man that he goes beyond and exceeds himself: man passes beyond and above his own physical means. They have to conclude that only the infinite and incomprehensible can comprehend man, and thus tell him of and show him to himself; only God can reveal man to man, because man only reveals himself by revealing, without knowing it, the one whose image he bears. If this image is obscured or abandoned (in favor of the objectivity of man according to some worldly laws and paradigms), man can no longer appear in the proper context of their predestined humanity, but disfigure themselves by attempting to refer their "image" to something other than themselves, that is by allowing themselves to resemble something other than God. And this constitutes the definition of sin: man thinks he attains unto himself by choosing to resemble less than God. It is this dissimilarity with the image that devalues man making them devoid of God so that man loses the human face as an icon of God: man's soul "is not sufficient to itself, nor is anything at all sufficient to him, who departs from Him, who is alone sufficient". ${ }^{51}$

One now can conjecture that man's solitude in the world is de facto their own existence in the conditions of the inherent incapacity to know themselves and then to know the sense of life. While attempting to verbalize this unknowability man discovers the paradox and contradiction of their condition, that contradiction which constitutes ultimately the content of the only mystery in the world. According to Nesmelov this mystery is not reduced to our present ignorance or principal inability in the future to know about the existence of God as the absolute archetype of man as person. Even if this knowledge could be acquired on the ways of spiritual life and communion with God, the question would remain as to why, by having such a knowledge, man cannot live in accordance with it. Even if every man realized himself as an image of God, this sense of being from God entirely contradicts to the actual existence of man as a simple thing in this world. Then the question of how to alleviate this contradiction, or how to avoid the existential incertitude and the feeling of solitude, homelessness and non-attunement to being, the anxiety and non-sense of being born into this world without knowing why and for what purpose, can only be to appeal to Christianity (which recognizes this mystery and proposes to solve it on the grounds of practice, rather than theory), assuming that it indeed inheres in itself the potential of that which makes the hope for the resolution of the paradox (Nesmelov 1905, p. 418). This is the reason why, according to Nesmelov, "man aspires not only to the explanation of his 
position in the world, but also to knowledge of that way through which he could indeed overcome this position... To reach knowledge of the eternal mystery of being means the same as to de facto remove this mystery in being, that is to produce the true way for accomplishment by man of his destiny in the world and give him true possibility for the accomplishment of this destiny. It is about this way and this possibility that Christian teaching tells man. It communicates to man that knowledge without which man cannot manage, but which he, unfortunately, cannot create" (Nesmelov 1905, pp. 409-410). ${ }^{52}$

\section{Instead of Conclusion}

Now one can attempt a generalisation from what we have discussed above. Humanity's sense of existence can be described in terms of three equivalent ways: as existence in solitude, as existence with no sense, as existence whose meaning can never be known (understood). On the level of human psychology this leads to fear of both life and death, that fear which enslaves humanity and chains it to its earthly fate whose major feature is the concealment of truth not only in an abstract sense but, first of all on the level of existence and action. According to Russian philosophers the slavery to the fear of death cascading towards society, politics and economics, perpetuates death to an ever greater extent. ${ }^{53}$ Berdyaev still refers this post-lapserian atavism to the underscoring of personhood, its under-development and overall impotence of man to reach its fullness. He identifies this insufficiency of man with his finitude which emerges when the manifestation of the Unconditional Absolute in him is dimmed because of slavery to death. Berdyaev advocates for the rediscovery of infinity and eternity in the hidden propensity of the Fallen humanity, that propensity which is still archetypically present through the impetus of restoration of the Divine
Image (Berdyaev 1943, p. 251). Here the impetus finds its fulfilment in creativity as manifestation of freedom: "Victory over death cannot be evolution, cannot be a result of necessity. Victory over death is creativeness, the united creativeness of man and God, it is a result of freedom" (Berdyaev 1943, p. 252). ${ }^{54}$ Creativity as freedom brings man to an ecstatic exit from time towards an instantaneous synthesis of being where all modalities of space (generating the sense of loneliness and solitude) and time (perpetuating despair) are suspended and the human spirit achieves a climax in its practical imitation of it Creator - he creates novelty in art, in the human reality and in the world itself. Creativity as freedom, as the overcoming of the solitude, non-sense and incomprehensibility of existence, makes a breakthrough from this world to a new and transfigured world. And the very possibility of this break into the other world is inherent in the God-given possibility for a symphonic and creative economy in this world as good creation by the Good God. The fulfillment of personood is a constant transcendence of the mundane and selfevident, the overcoming of the constraints and slavery to the rubrics of the incarnate existence in this physical world. It is in this movement that the sense of solitude and despair disappears because the whole of the human history, as well as the whole universe, are brought inside the infinite and incomprehensible subjectivity of man in the image of the Divine. Thus freedom and creativity imply such a transformation in the vision of the world (as a vast and nonsensical universe) where human personhood acquires back its central place in the universe. But this is an ideal of Godmanhood so heartedly fostered by practically all Russian religious philosophers. Here philosophy inevitably merges with the theology of deification that demands a different approach to the present subject matter that exceeds the objectives and scope of this article. 
All those Russian philosophers quoted in this paper expressed a deep thought and care for man, the world and God. They were looking for the consolation of the soul of all humanity from within a limited historical period in the $20^{\text {th }}$ century's history full of apostasy and demonic inhumanity, causing the lament of the whole created universe. Their hymnology to man is the perennial attempt to affirm this world as still imbued with faith, hope and love.

\section{Acknowledgement}

I would like to express my feeling of gratitude to George Horton, who kindly read the manuscript and made some valuable suggestions on how to improve the style of the text.

In this paper we use English translations of Russian philosophers, either already translated in different editions, or translated by us. In order to preserve an academic vigor and give a chance to the reader to experience all depth of the Russian philosophical language, we also provide the original text in Russian with a corresponding reference by denoting it RO Russian Original.

2 RO: «Всякая жизнь стремится подняться над землей и неизбежно вновь на нее ниспадает, смешиваясь с прахом; а крылья, на которых она взлетает, оказываются лишь прозрачной и исчезающей поэтической прикрасою» (Трубецкой 1922, с. 34).

3 RO: «Именно личности глубоко присуще состояние ужаса и тоски. Человек чувствует себя существом висящим над бездной и именно в человеке, как личности, оторвавшемся от первоначальной коллективности, это чувство достигает особенной остроты» (Бердяев 1939, с. 45).

4 Emphasis added. RO: «Наша “душа”, наше “я” испытывает некую присущую ей нужду и недостаточность, некий имманентный трагизм своего существования.... [в той мере как] она вообще достигает подлинного самосознания, она роковым образом сознает свое одиночество, свою бесприютнсть в составе объективной действительности, в которой она обречена соучаствовать и которой она в значительной мере подчинена» (Франк 1997, с. 180-81) (курсив наш, АН).

"Le silence éternel des ces espaces infinis m’effraie" (Pascal 1962, p. 110).

RO: «Тоска устремлена вверх и обличает высшую природу человека» (Бердяев 1939, с. 45).

Modern cosmology persuasively demonstrates that the spatial volume of man's location in the universe on the planet Earth constantly decreases due to the fact that at the level of clusters of galaxies the universe expands with acceleration. A typical scale of the human embodiment does not change for it is determined by the gravitational forces responsible for the stability of the geocentric environment.

8 RO: «Познающий субъект лишен всякого внутреннего существования, не имеет точки опоры в бытии, он существует лишь в отношении производимой им объективации» (Бердяев 2003[1], с. 53).

9 It is in this context that S. Bulgakov qualified science as a kind of economy which human being is doomed to deal with because of its condition: "Man stands in an economic relation to nature, holding a tool in one hand and the flaming torch of knowledge in the other. He must struggle for his life, that is, engage in economic activity. Science is also born in this struggle, it is its instrument and outcome” (Bulgakov 2000, p. 166). (RO: «Человек стоит в хозяйственной позе по отношению к природе, с рабочим инструментом в одной руке, с пламенеющим светочем знания в другой. Он должен бороться за свою жизнь, т.е. вести хозяйство. Наука родится тоже в этой борьбе, есть ее орудие и порождение» (Булгаков 1993, с. 182)). In another passage Bulgakov writes: "Science is an attribute of man, his tool, which he creates for one or another task. Science is thoroughly anthropological and, insofar as actuality and economy in labor is the essential nerve of human history, science is also economic, or pragmatic. In order to understand science we must understand man.”(Ibid., p. 172) (RO: «Наука есть атрибут человека, его орудие, которое он создает для тех или иных задач. Наука насквозь антропологична, и насколько трудовая актуальность и хозяйственность есть основной нерв человеческой истории, то наука и хозяйственна и прагматична» (Там же, с. 188)).

10 RO: «Космос, человечество, нация и пр. находятся в человеческой личности, как в индивидуализированном универсуме или микрокосме и выпадение, выбрасывание их во внешние реальности, в объекты, есть результат падшести человека, подчинения его безличной реальности, экстериоризации, отчуждению» (Бердяев 1939, с. 37).

11 RO: «Никакой целостности, тоталитарности, универсальности вне личности нет, есть лишь в личности, вне ее есть лишь частичный, объективированный мир» (Бердяев 1939, с. 37).

12 RO: «трудовым восстановлением идеального космоса как организма идей или идеальных закономерностей, гармонично сочетающих космические силы или формирующих первоматерию и первоэнергию, «праматерь» бытия. В этом процессе «наука проникает через кору и толщу хао-космоса к идеальному космосу, космосу-Софии» (Булгаков 1993, с. 211).

13 RO: «орудие оживления мира, победы и самоутверждения жизни» (Булгаков 1993, с. 192).

14 The abovementioned paradox was coined by E. Husserl as "the paradox of human subjectivity being a subject for the world and at the same time being an object in the world" (Husserl 1970, p. 179). The paradox received numerous formulations and interpretation by many philosophers, including such names as M. Merleau-Ponty, R. Ingarden M. Scheler and others. See (Carr 1999). See also my paper (Nesteruk 2014).

15 Oration 45, On Easter, 7 [ET: (Nellas 1997, p. 203)].

16 Maximus the Confessor, Ambigua 41, [PG 91, 1304-1312B], [ET: (Nellas 1997, p. 212)]. 
17 Maximus the Confessor, Ambigua 10:26, [PG 91, 1153B], [ET: "Various Texts on Theology, the Divine Economy, and Virtue and Vice" 5:71, in The Philokalia, v. 2, p. 277].

18 RO: «Современный человек сознает себя внутренне свободным, сознает себя выше всякого внешнего, от него не зависящего начала, утверждает себя центром всего и между тем в действительности является только одной бесконечно малой точкой на мировой окружности...С одной стороны, человек есть существо с безусловным значением, с безусловными правами и требованиями, и тот же человек есть только ограниченное и преходящее явление, факт среди множества других фактов, со всех сторон ими ограниченный и от них зависящий, - и не только отдельный человек, но и все человечество...» (Соловьев 1989, с. 21).

19 RO: «Человек совмещает в себе всевозможные противоположности, которые все сводятся к одной великой противоположности между безусловным и условным, между абсолютною и вечною сущностью и преходящим явлением, или видимостью. Человек есть вместе и божество и ничтожество» (Соловьев 1989, с. 113).

20 RO: «В личности есть природные основы, связанные с космическим круговоротом. Но личное в человеке иного происхождения и качества и всегда означает разрыв с природной необходимостью...Человек, как личность, не есть часть природы, он несет в себе образ Бога. В человеке есть природа, но он не есть природа. Человек - микрокосм и потому он не есть часть космоса» (Бердяев 1939, с. 81) Compare with an analogous assertion of S. Frank: “...man, though forming part of 'this world', transcends it, for he has another, non-worldly aspect which differentiates him from this this world...” (Frank 1965, p. 110), or “...Man is an entity capable of withdrawing from all that exists as a fact (including his own actual existence), of considering it from outside and determining its relation to something other, which is more convincing to him and is primary and authoritative" (Ibid., pp. 111-12) (RO: «...человек, также входя в состав «этого» мира и в нем соучаствуя, одновременно возвышается над ним, имея в себе иную, сверхмирную инстанцию», или «Человек есть существо, обладающее способностью дистанцироваться от всего, что фактически есть, - в том числе и от дейстивтельности себя самого - смотреть на все фактически сущее извне и определеить его отношение к чему-то иному, более для него убедительному, авторитетному, первичному» (Франк 1997, с. 202, 204)).

21 RO: «Положение человека в природном мире трагическое. Человек не только один из объектов этого мира, он прежде всего субъект, из объекта невыводимый. Вместе с тем отношение человека к космосу определяется тем, что он есть микрокосм, он заключает в себе космос или заключает в себе всю историю..... Через духовное в себе начало человек не подчинен природе и независим от нее, хотя природные силы могут его убит [ср. Паскаль, АН]... Он раб природы и царь природы» (Бердяев 2003[2], с. 588).

22 RO: «И природа и человек бесконечны; и по бесконечности своей, как равномощные, могут быть частями самих себя, причем части равномощны между собою и целым. Человек- в мире, но человек так же сложен, как и мир. Мир в человеке, но и мир также сложен, как и человек» (Флоренский 1994, с. 186).

23 RO: «..человек есть сумма Мира, сокращенный конспект его; Мир есть раскрытие Человека, проекция его» (Флоренский 1994, с. 187).

24 Translation from the Russian is substantially corrected. RO: «Человек есть, с одной стороны, потенциально все, потенциальный центр антропо-космоса, хотя и не реализованного еще, но реализуемого, а с другой стороны - он есть продукт этого мира, этой эмпирии» (Булгаков 1993, с. 160).

25 RO: «Через свое тело и плотскую жизнь, через внешний, наружный слой своей душевной жизни, определенной связью с телом, человек есть сам часть “объективной действительности”, часть “мира”, в котором и из которого он рождается и в котором пребывает.... Через свои глубины - через ядро или корень своего бытия и в этом смысле через свое подлинное существо - он принадлежит к составу сверхмирной первичной реальности (в которой, как мы видели, укоренен и из которой в конечном счете проистекает и сам мир...). Человек есть, таким образом, двухсоставное существо, и всякое учение о жизни, которое не учитывало бы одновременно этих двух сторон человеческого бытия, было бы неадекватно его подлинному существу...Структура нашего бытия сложна, антиномична, и всякое ее искусственное упрощение и схематизация искажают ее» (Франк 1997, с. 70-71).

26 Compare with Berdyaev's assertions that "the cosmos, mankind, society, are in personality and not the other way around" (Berdyaev 1943, p. 38; see also pp. 42, 135) (RO: «космос, человеческтво, общество находятся в личности, а не наоборот» (Бердяев 1939, с. 34; см. также с. 37, 114). See also a similar thought on humanity as the hypostasis of the universe (Clément 1976, p. 91).

27 As was carefully discussed by Gilles Deleuze, in art there is a fundamental irreplaceability of a masterpiece by something which belonged to the generality of the works of art. Every attempt to reproduce an incarnate artistic expression would require a repetition as an irreversible bringing into being of that which did not exist before. Since masterpieces do reflect artists' souls and their distinct personhood, they cannot be substituted and replaced because of the same reasons that persons cannot be substituted and replaced. (See more details in (Deleuze 2001, pp. 1-27)).

28 S. Bulgakov expressed his attitude to the objectivising tendencies of the sciences of his time on the basis of a criticism of its fragmented description of reality and limited capacity of comprehending the world as living nature. The mathematical universe expels living subjects by converting it into the kingdom of shadows and "subjectless" objects: "Science deliberately commits a murder of the world and of nature, it studies nature's corpse” (Bulgakov 2000, p. 183) (RO: «наука творит заведомое мироубийство и природоубийство, она изучает труп природы...» (Булгаков 1993, с. 199)). Bulgakov realises, just as Berdyaev did, the fundamental paradox of science: on the one hand science transforms the world into a lifeless mechanism, on the other hand, science itself was produced through the subject's contingent self-definition (Ibid., p. 188. RO: c. 205). The source of science, the foundation of its possibility, is to be found in humanity. Otherwise science becomes no more than an ingenious tool whose ultimate sense remains utterly obscure. Bulgakov anticipated this way of thought by formulating the thesis that to understand science one should turn to the understanding of man. It is not science that explains man, but man who explains science. Philosophy of science is a branch of philosophical anthropology (Ibid., p. 173. RO: c. 188). 
29 See, for example (Berdyaev 1953, p. 41).

30 RO: «Личность не есть часть, и не может быть частью в отношении к какому-либо целому, хотя бы к огромному целому, всему миру....Личность не составляется из частей, не есть агрегат, не есть слагаемое, она есть первичная целость» (Бердяев 1939, с. 20, 21).

31 RO: «Тайна существования личности в ее абсолютной незаменимости, в ее однократности и единичности, в ее несравнимости» (Бердяев 1939, с. 22).

32 RO: «Личность связана со свободой от детерминизма природы, она независима от механизма природы. Поэтому личность не есть феномен среди феноменов» (Бердяев 1939, с. 30).

33 RO: «Личность не порождается родовым космическим процессом, не рождается от отца и матери, она происходит от Бога, является из другого мира» (Бердяев 1939, с. 32).

34 The analogy comes from St. Maximus the Confessor's assertion that God knows things according to his will (Ambigua 7 [PG 91: 1085B]).

35 RO: «...и если в развитии положительных знаний о мире весь мир наконец сделается известным для человека, то этим познанием о мире фактическое противоречие в бытии самого человека все таки не будет устранено и поэтому определение смысла этого противоречия неизменно будет составлять для человека великую загадку бытия» (Несмелов 1905, с. 242).

$36 \mathrm{RO}:$ «еловек должен восстать против рабства истории не для изоляции в самом себе, а для принятия всей истории в свою бесконечную субъективность, в которой мир есть часть человека» (Бердяев 1939, с. 221).

37 RO: «...всякая попытка человека осуществить в мире природное содержание своей личности путем развития физического содержания жизни необходимо заключает в себе неразрешимое внутреннее противоречие и естественно ни к чему не ведет человека» (Несмелов 1905, с. 243).

38 RO: «при всех своих огромных успехах в культурном преобразовании действительности человек все таки остается...простою вещью мира, которая и возникает и разрушается лишь в силу необходимых законов физической природы и потому неведомо зачем существует под формою личности» (Несмелов 1905, с. 243).

39 RO: «..все частные противоречия мысли и жизни возникают из стремления человека осуществить идеальный образ безусловного бытия в необходимых границах внешних условий» (Несмелов 1905, с. 246).

40 RO: «...Личностью может быть одно только безусловное бытие, - это каждый человек непосредственно сознает и достоверно знает в познании самого себя» (Несмелов 1905, с. 264).

41 RO: «Но, существуя в качестве личности и в то же самое время необходимо связанный механизмом внешних условий в качестве простой вещи физического мира, человек не есть безусловное бытие, а только предметно выражает в себе реальную связь условного и безусловного бытия, и потому, не зная о существовании другого мира, кроме наличного, он достоверно знает о существовании другого бытия, кроме условного, так как он в себе самом предметно выражает двоякое бытие - условное и безусловное. Если бы загадочный факт этого выражения не отрицался в мнимонаучных объяснениях его, а действительно объяснялся, как и всякий непонятный факт факт бытия, то научная мысль вероятно давно бы пришла к библейскому учению о создании человека по образу Божию, потому что существование человека как реального образа Безусловной Сущности, строго научно может быть установлено и независимо от Библии, на основании одного только психологического анализа природы и содержания человеческой личности, и к Библии можно обратиться не затем, чтобы почерпнуть из нее это учение, а только за тем, чтобы найти в ней объяснение действительного факта. И объективное бытие Бога, и достоверное познание природы Его непосредственно даны человеку реальным бытием и природным содержанием его собственной личности, но почему и как именно возможна в условном бытии сама-то человеческая личность, как реальный образ Бога, - этого мы не знаем и не можем знать, и Библия говорит нам о создании человека действием Божией воли» (Несмелов 1905, с. 264-65).

42 RO: «И мы достоверно знаем в познании себя самих, что хотя наша собственная личность существует только в необходимых условиях физического мира, однако природою своею она все-таки выражает не мир, а истинную природу самого Бесконечного и Безусловного, потому что бесконечное и безусловное есть не иное что, как свободное бытие для себя, а свободное бытие для себя и есть и может быть только бытием самосущной Личности» (Несмелов 1905, с. 269).

43 RO: «Следовательно, содержанием нравственного сознания выражается не что иное, как природное самоопределение человеческой личности в условиях ее физического существования: нравственно для человека то, что должно быть осуществляемо человеком, а должно быть осуществляемо человеком то, что истинно человечно, а истинно человечно то, что выражает собой действительную природу человеческой личности независимо от условий, интересов и целей ее физического существования» (Несмелов 1905, с. 287).

44 RO: «Но в том-то именно и заключается все дело, что истинная жизнь, о которой говорит человеку нравственное сознание, в действительности неосуществима, потому что человек существует не только в качестве свободного деятеля в мире, но и в качестве простой вещи мира, необходимо подчиненной всеобщим законам физического существования» (Несмелов 1905, с. 287-88).

45 Emphasis is added. RO: «конечным результатом науки о человеке в сущности является только неразрешимая загадка о нем: как он мог появиться в мире, когда природою своей личности он необходимо отрицает его [то есть мир, АН], сам в свою очередь отрицается миром?» (Несмелов 1905, с. 372) (курсив мой АН).

46 RO: «вся его рассчитанная добродетель в действительности покоится только на презрении к миру и на отрицании его, а вовсе не на желании раскрыть в нем и посредством него истину нравственного миропорядка и в этом раскрытии отобразить в мире жизнь Безусловной Личности» (Несмелов 1905, с. 391).

47 This ontological difference can be illustrated as a contrast between humanity as consubstantial to the rest of creation on the one hand and as hypostatic formation on the other hand. Indeed, being inseparable from reality in virtue of its 
embodiment, human persons can exist only in the context of their immediate non-distance from reality (consubstantiality). On the other hand, being a hypostatic formation (humanity is endowed with an ability to inhere the universe in its own subjectivity through the fusion of knowledge, to form the meaning and act in the universe as its self-consciousness and self-realization, or, theologically speaking, as its hypostasis), that is being fundamentally different from other material things, human persons are "infinitely" ontologically distant from those other things. The ability to distance themselves from outer things (even, in abstraction, from one's own body), makes human persons equally positioned with respect to all objects in the universe, so that they can be articulated by human subjectivity as different and uniformly distant from it. Paradoxically, on the one hand, because of the infinite ontological distance from all things in the universe humanity is hypostatically commensurable (and thus equally close) with respect to all objects in the universe, including the universe as a whole, whereas on the other hand, being corporeally at non-distance from the universe, humanity is physically incommensurable with the universe.

48 Gregory of Nyssa, "On the Making of Man," in Selected Writings and Letters Gregory of Nyssa trans. W. Moore and H. A. Wilson, vol. 5 of NPNF, Series II, ed. Ph. Schaff and H. Wace (Grand Rapids, Mich.: Eerdmans, 1994), pp. 396-97.

49 St. Augustine, Confessiones 10.5.7 [ET: (Chadwick 1991, pp. 182-83)].

50 See a comprehensive account on the unknowability of man in (Marion 2010, pp. 21-86).

$51 \quad$ St. Augustine, De Trinitate, 10.5.7 [ET: (McKenna 2002, p. 50)].

52 RO: «человек и стремится не только к объяснению своего положения в мире, но и к познанию того пути, по которому он действительно мог бы выйти из этого положения...Достигнуть же познания вечной тайны бытия значит тоже самое, что фактически устранить эту тайну в бытии, то есть создать действительный путь к осуществлению человеком его назначения в мире и дать ему действительную возможность к фактическому осуществлению этого назначения. Об этом именно пути и об этой возможности и говорит человеку христианское вероучение. Оно сообщает то самое познание, без которого человек не может обойтись и которого, однако он не может создать» (Несмелов 1905, с. 409-410).

53 "From fear of death man sows death, as a result of feeling a slave, he desires to dominate. Domination is always constrained to kill. The state is always subject to fear and therefor it is constrained to kill. It has no desire to wrestle against death" (Berdyaev 1943, p. 251) (RO: «Человек из страха смерти сеет смерть, из чувства рабства хочет господствовать. Господство всегда принуждено убивать. Государство всегда испытывает страх, и потому принуждено убивать. Оно не хочет бороться со смертью», (Бердяев 1939, с. 209)). A manifesting discrepancy between the desire to find the sense of life on the one hand, and the collective state-like life of man where human dignity is dismissed was described by E. Trubetskoi in following words: "On the one hand there is a powerful appeal of love to every man, on the other hand all peoples are armed from top to toe for the mutual extermination. On the one hand there is an attempt of man to break the closed loop of the struggle for survival, to rise from the Earth in a joyous enthusiasm of love and, on the other hand, there is another illustration of the impotence of any of such an attempt, namely the state with its periodically repetitive and triumphant slogan all is for war (Trubetskoi 1922, p. 38) (RO: «С одной стороны - властный призыв любви ко всякому человеку, как таковому, а с другой стороны, - все народы вооружены с головы до ног для взаимного истребления. С одной стороны - попытка человека прорвать порочный круг всеобщей борьбы за существование, взлететь над землей в светлом подъеме любви, а с другой стороны, новая иллюстрация бессилия этой попытки, - государство с его периодически повторяющимися и периодически торжествующим лозунгом - все для войны» (Трубецкой 1922, c. 38)).

54 RO: «Победа над смертью не может быть эволюцией, не может быть результатом необходимости: победа над смертью есть творчество, совместное творчество человека и Бога, есть результат свободы» (Бердяев 1939, с. 210).

\author{
Abbreviations \\ RO: Russian Original \\ NPNF: The Nicene and Post-Nicene Fathers, ed. P. Schaff and H. Wace (Grand \\ Rapids, MI: W. B. Eerdman Publishing Company, 1996). \\ PG: ed. J. P. Migne, Patrologia Graeca, 161 vols, (Paris, 1857-66). \\ The Philokalia: St. Nikodimos of the Holy Mountain and St. Makarios of Corinth. The \\ Philokalia: The Complete Text, 4 vols., ed. G. E. H. Palmer, P. Sherrard, and K. Ware, (London:
} Faber, 1979-95).

\title{
References
}

1. Augustine, Confessiones [ET: tr. H. Chadwick, Confessions, (Oxford: Oxford University Press, 1991)].

2. Augustine, De Trinitate [ET: ed. G. B. Matthews, tr. S. McKenna, On the Trinity, Books 8-15 (Cambridge University Press, 2002)]. 
3. Berdyaev, N., Slavery and Freedom (London: Geoffrey Bles, 1943) (RO: Н. А. Бердяев, O рабстве и свободе человека, Paris: YMKA-Press, 1939).

4. Berdyaev, N. Truth and Revelation (London, Geoffrey Bles, 1953).

5. Berdyaev, N., Philosophy of Freedom (Moscow: Pravda, 1989) (In Russian: H. А. Бердяев, Философия свободы, М: Правда, 1989).

6. Berdyaev, N., “"I" and the world of Objects", in his Spirit and Reality (Moscow: AST, 2003[1]), pp. 25-156 (In Russian: Н. А. Бердяев, «Я» и мир объектов// Дух и реальность, Москва: ACT, 2003[1], c. 25-156).

7. Berdyaev, N., "The Kingdom of Spirit and the kingdom of Cesar", in his Spirit and Reality (Moscow: AST, 2003[2]), pp. 567-671 (In Russian: Н. А. Бердяев, Царство духа и царство Кесаря// Дух и реальность, Москва: АСТ, 2003[2], с. 567-671).

8. Bulgakov, S., Philosophy of Economy. The World as Household, tr., ed. Catherine Evtuhov (New Haven and London: Yale University Press, 2000) (RO: C. Н. Булгаков, Философия хозяйства, в соч. в 2х т., т. 1, М.: Наука, 1993).

9. Carr, D., Paradox of Subjectivity (Oxford: Oxford University Press, 1999).

10. Clément, O., Le Christ Terre des Vivants. Essais Théologiques. Spiritualite Orientale, n. 17 (Bégrolles-en-Mauges: Abbaye de Bellfontaine, 1976).

11. Deleuze, G., Difference and Repetition (London and New York: Continuum, 2001).

12. Florensky, P., "Macrocosm and Microcosm", in his Apology of the Cosmos (St. Petersburg: Russian Christian Humanitarian Institute, 1994), pp. 184-201 (in Russian: П. Флоренский, Макрокосм и микрокосмос//Оправдание космоса. СПб.: РХГИ, 1994, с. 184-201).

13. Frank, S. L., Reality and Man (New York: Taplinger Publ. Co., 1965) (RO: С. Л. Франк, Реальность и человек, СПб.: РХГИ, 1997).

14. Gregory of Nyssa, "On the Making of Man," in NPNF, vol. 5, pp. 387-427.

15. Gregory the Theologian (Nazianzus), Oration 45 [ET: in (Nellas1997, pp. 203-205)].

16. Husserl, E., The Crisis of the European Sciences and Transcendental Phenomenology. (Evanston: Northwestern University Press, 1970).

17. Kant, I., Critique of Practical Reason, Conclusion, in Kant's Critique of Practical reason and Other Works on The Theory of Ethics, tr. T. K. Abbot (London: Longmans, 1959).

18. Kierkegaard, S., Repetition and Philosophical Crumbs, tr. M. G. Piety (Oxford: Oxford University Press, 2009).

19. Marion, J.-L., Certitudes negatives (Paris: Bernard Grasset, 2010).

20. Maximus the Confessor, Ambigua 10:26 [PG 91: 1153B]; [ET: "Various Texts on Theology, the Divine Economy, and Virtue and Vice" 5:71, in The Philokalia, vol. 2, p. 277].

21. Maximus the Confessor, Ambigua 41 [PG 91: 1304-1312B], [ET: (Nellas 1997, p. 212)].

22. Nellas, P., Deification in Christ. Orthodox Perspectives on the Nature of the Human Person (Crestwood: St. Vladimir's Seminary Press, 1997).

23. Nesmelov, V., The Science of Man, vol. 1 (Kazan: Central Printing House, 1905) (In Russian:

В. И. Несмелов, Наука о человеке, т. 1, Казань: Центральная типография, 1905).

24. Nesmelov, V., Faith and Knowledge from the Point of View of Epistemology (Kazan: Central Printing House, 1913) (In Russian: В. И. Несмелов, Вера и знание с точки зрения гносеологии, Казань: Центральная типография, 1913). 
25. Nesteruk, A. V., "Humanity in the Universe: between Embodied Incommensurability and Intentional Infinitude", Journal of Siberian Federal University. Humanities \& Social Sciences 7, № 6 (2014), pp. 1304-35.

26. Pascal, B., Pensées. Tr. Louis Lafuma (Paris: Éditions du Seul, 1962).

27. Primack, J., Abrams, N. E., The View from the Centre of the Universe. Discovering our Extraordinary Place in the Cosmos (London: Fourth Estate, 2006).

28. Soloviev, V., Readings on Godmanhood (Moscow: Pravda, 1989) (In Russian: В. С. Соловьев, Чтения о Богочеловечестве, М.: Правда, 1989).

29. Trubetskoi, E., The Sense of Life (Berlin: Slovo, 1922) (In Russian: Кн. Е. Трубецкой, Смысл жизни, Берлин: Книгоиздательство «Слово», 1922).

\title{
От одиночества к свободе:
}

\section{человеческая личность и Вселенная \\ В русской религиозной философии}

\author{
A.В. Нестерук \\ Университет Портсмута \\ Лайон Гэйт Бюлдинг \\ ПОРТСМУТ, РОІ ЗНF, Великобритания
}

\begin{abstract}
В статье обсуждаются проблемы тревоги, одиночества, бесприютности и бессмысленности человеческого существования в той форме, в какой они были сформулированы в русской религиозной философии XX века. Русские философы искали пути преодоления такого состояния человека на путях восстановления утраченного Божественного образа, выражаемого с помощью представления о личностности. Трудность в определении личности проистекает из парадоксального состояния человека во Вселенной (являющимся предметом вечной философии), а также непознаваемости человека самим собой (осознанной Отиами ранней Церкви). Достижение существования в полноте личности предполагает преодоление ограничений и рабства воплощенного существования в физическом мире. В этом духовном движении ощущение одиночества и безысходности преодолевается, ибо вся человеческая история, как и вся Вселенная, артикулируется и приобретает смысл изнутри бесконечной и непознаваемой субъективности человека в Божественном образе. Русские философы были глубоко озабочены состоянием человека и его взаимоотношениями с миром и Богом, осуществляя поиск путей утешения души всего человечества в ограниченный исторический период XX века, насыщенного отступничеством и бесчеловечностью. Гимн русских философов человеку был вкладом в нескончаемые усилия по утверждению мира как попрежнему наполненного верой, надеждой и любовью.
\end{abstract}

Ключевые слова: абсолютное бытие, Вселенная, личность, объективация, одиночество, русская философия, свобода, человек.

Научная специальность: 09.00.00 - философские науки. 